research on such subjects as flavour chemistry, the pro. teins of rnilk, fat oxidation and micro-strueture of certain milk products, and yet at the same time much is being done which is of immediate practical application on a commercial scale. For example, for the manufacture of casoin a new method of precipitation has been devised. When the previous annual report was written, this method was only at the pilot plant stage, but already it is being widely usod in Australia with probable savings of some $£ 150,000$ a year. Much has been done also on the mechanization of cheese manufacture, a subject of world-wide importance, and it is significant to note that some of the machines that have been evolved in Melbourne for this purpose have already been exported to Britain and the United States. Then again, a cheesc-drying process developed here is now being used successfully not only in Australia but also in Japan. The achievements of this Division illustrate the outstanding progress that can be made when basie science and its practical application on a manufacturing scale are both actively encouraged in one and the same institution.

\section{Nocturnal Intensity Recorder}

InstRUMENTS for tho measurement of the intensity of the night airglow usually consist of a photoolectric-type photometer with narrow band-pass filters or with birefringent filters, and are made either to look at a fixed portion of tho sky or to scan the sky at various altitudes snd azimuths. A new instrument, called a 'Noctinograph' (Nocturnal Intensity Recorder), has been designed and built in the Radio and Electrical Engineering Division of the National Research Council, Ottawa, Canada. The instrument scans the entire dome of the sky and records the intensities of the night sky radiations in four wave. lengths of the visible spectrum several times during a night according to a predetermined programme. It consists of a scanning-type photometer with four, replaceable, very narrow, band-pass interference filters, and is installed on the roof of the Springhill Meteor Observatory near Ottawa. A detailed description of the instrument and its performance is given by F. V. Kulkarni and J. C. Barnes in the January issue of the Canadian Journal of Physics $(42,1 ; 1964)$. The five components of the 'Noctinograph' consist of the scanner, recorder, twilunar clock, mixer chassis, and power pack and amplifier. The scanner automatically scans the sky in coneentric circles around the zenith. The EMI $9560 B$ photomultiplier is mounted on an altazimuth mounting. Scanning with ono filter takes $3.5 \mathrm{~min}$ and with all four filters a total of $14 \mathrm{~min}$. The scanner and rocorder then rest for $16 \mathrm{~min}$ and the next scan begins after a half.hour pulse has been received from the twilunar clock. A set of recorded scans taken on the nights of May 21-22, 1963, are shown in the articlo. Tntensitios obtained with the $5400 \AA$ filter are less than those obtained with the $5577 \AA$ filter at all points in the sky. The first filter is usod to soe the 'back. ground', and tho second filtor gives the intensity of $[0]_{1}$ line together with the background. The other two filters, transmitting around $6300 \AA$ and $6257 \AA$, serve to separate the $[0]_{1}^{1}{ }^{1} D_{2}-{ }^{3} P_{2}$ line from the $(9-3) \mathrm{OH}$ band head at $6257 \AA$.

\section{Stratigraphy of the U.S.S.R.}

IN 1963 the Academy of Sciences in Moscow announced the forthcoming publication of a monumental series of fourteen large volumes on the stratigraphy of tho U.S.S.R., sponsored jointly by the Academy, the State Geological Committeo, and the Ministry for Higher Spocialist Education. The first work to appoar in this library is a well produced monograph on the Upper Procambrian (Riphaean) formations (Stratigrafiya SSSR: Verkhnii Dokembrii. (Stratigraphy of the U.S.S.R.: Uppor Precambrian.) Pp. $716+94$ figs. +18 pl. Gosgeoltekhizdat, Moscow, 1963. Price 4r. 85k. (Russian only)). This is of special interest since unmetamorphosed rocks of this age (from 1,500 m.y. to $570 \mathrm{~m} . \mathrm{y}$. ago) are extensively developed within the U.S.S.R., and a proper understanding of their nature is fundamental to the resolution of many debated problems of Earth history. The book is a cooperativo effort by many authors, but the overall responsibility of co-ordinating and editing it (in addition to that of writing many chapters) has been admirably discharged by Dr. B. M. Koller. Two-thirds of its pages are taken up with regional stratigraphical detail, and this is followed by chapters on palæontology (with 18 platos illustrating stromatolites, medusæ, and other primitive fossils), on radiometric dating, on tillites and rolated glacial sediments, on topies such as trans-continental and world-wide corrolation, palæogeography and general questions of the contemporary development of the Earth's crust, and finally on ore doposits. The last-mentioned include jaspilite-type iron quartzites, extensive metasomatic siderite ores in carbonate sediments, manganese ores, magnesite deposits, indications of bitumens, oil and gas, and the important and widespread Upper Procambrian phosphorite deposits discovered in tho past decade. 'The primitive fossils, the hydrocarbons and the phosphorites point to the existonce of abundant organisms in Uppor Precambrian times. An extensive bibliography occupies 30 pages, and there are welcome indexes of stratigraphical, geographical, palæontological and personal names.

\section{Standardization of Diamond Abrasive Grit}

DIAMOND grit, or 'splint' as it is sometimes known, finds very considerable use in a variety of industries, notably those concerned with the use of masonry and concrete saws, metal-l onded and resin-bonded grinding wheels, and in lapidary laboratories and workshops for arming mild-steel mineral and rock-cutting disks. It would appear that hitherto there has bcen little attempt at standardization of this important product, not only as regards quality but also more particularly in terms of strength as a function of grit size. According to N. G. Belling and H. B. Dyer, in a publication entitled Impact Strength Determination of Diamond Abrasive Grit, particle strength is the factor which has most influence on diamond grit efficiency ( $\mathrm{Pp}$. 12. London: The Industrial Diamond Information Burcau, 1964). Generally, with saws and metal-bonded wheels, it is found that optimum strength is the maximum strength obtainable. "For resin-bonded grinding wheels, the situation is more complex. First, the optimum strength is a function of the grit size. Secondly, for a given size, the optimum strength varies with the type of resin bond used. A strength appreciably higher or lower than the optimum results in reduced wheel efficiency. Thus, a further criterion is that the grit must be as homogeneous as possible in terms of strength." In the experimental work involved it was necessary to define the particular strength property to be measured, and it appeared that in nearly all applications of diamond grit dynamic impact strength was the factor to be sought in determining the quality and efficiency of a grit. It was realized that whatever machine for this purpose was used, the method of strength measurement had to be quick, uncomplicated, capable of dealing with largo numbers of fine particles of arbitrary shape. In the event, what is known as the 'Friatest Impact Tester' was designed and built; details of this apparatus and illus. trations, also of its operation, are given in this paper. The authors conclude that the Friatest is a most valuable instrument and that with its use "the major problem of a reproducible test for diamond grit strength has largely been solved". The index of impact strength of a given grit can now be directly compared with values obtained on other grits in other laboratories. This technique permits standardization of quality control of the properties of various natural and synthetic diamond grits, and ultim. ately the widespread use of this apparatus should lead to a better understanding of the properties of these products, hence to their greatly improved characteristics. 